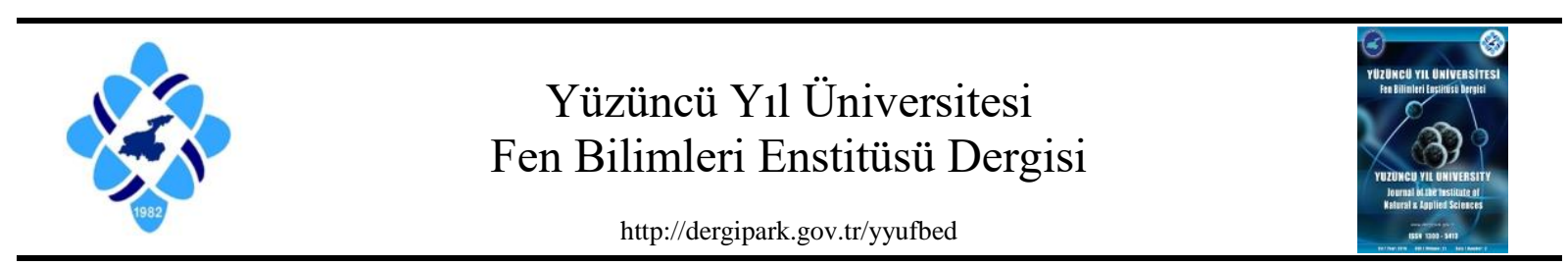

Araştırma Makalesi

\title{
Taşova (Amasya) Yöresinde Yetiştirilen 'Ekmek’ Ayva Çeşidinin Fiziksel ve Biyokimyasal Özellikleri
}

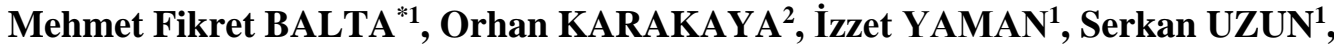 Hüseyin KIRKAYA ${ }^{3}$}

${ }^{1}$ Ordu Üniversitesi, Ziraat Fakültesi, Bahçe Bitkileri Bölümü, 52200, Ordu, Türkiye

${ }^{2}$ Sakarya Uygulamalı Bilimler Üniversitesi, Ziraat Fakültesi, Bahçe Bitkileri Bölümü, 54000, Sakarya, Türkiye

${ }^{3}$ Bolu Abant İzzet Baysal Üniversitesi, Seben İzzet Baysal Meslek Yüksekokulu, Bitkisel ve Hayvansal Üretim

Bölümü, 14750, Bolu, Türkiye

Mehmet Fikret BALTA, ORCID No: 0000-0002-3859-6490, Orhan KARAKAYA, ORCID No: 0000-0003-

0783-3120, İzzet YAMAN, ORCID No: 0000-0002-2576-7721, Serkan UZUN, ORCID No: 00-0002-3857-

6561, Hüseyin KIRKAYA, ORCID No: 0000-0001-8371-5324

*Sorumlu yazar: fikret_balta@hotmail.com

Makale Bilgileri

Geliş: 09.07.2021

Kabul: 05.11.2021

Online Aralık 2021

DOI: $10.53433 /$ yyufbed.967975

Anahtar Kelimeler

Ayva,

Meyve ağırlı̆̆

Şeker,

Fenolik,

Antioksidan
Öz: Çalışma, Amasya ili Taşova ilçesinde yetiştirilen 'Ekmek' ayva çeşidinin fiziksel ve biyokimyasal özelliklerini belirlemek amacıyla yürütülmüștür. Çalışmada meyve ağırlığ 305.43 g, meyve eti sertliği $62.50 \mathrm{~N}$, suda çözünebilir kuru madde miktarı \%11.64, titre edilebilir asitlik \%0.83, C vitamini içeriği 11.60 $\mathrm{mg} / 100 \mathrm{ml}$, glikoz içeriği $3.10 \mathrm{~g} / 100 \mathrm{ml}$, sukroz içeriği $1.87 \mathrm{~g} / 100 \mathrm{ml}$, fruktoz içeriği $7.62 \mathrm{~g} / 100 \mathrm{ml}$, toplam fenolik $121.8 \mathrm{mg} / 100 \mathrm{~g}$, toplam flavonoid 18.4 $\mathrm{mg} / 100 \mathrm{~g}$, antioksidan aktivitesi DPPH testine göre $0.46 \mathrm{mmol} / 100 \mathrm{~g}$ ve FRAP testine göre $2.67 \mathrm{mmol} / 100 \mathrm{~g}$ olarak belirlenmiştir. Sonuç olarak, 'Ekmek' ayva çeşidinin insan sağlığına faydalı ve hastalıklara karşı koruyucu bir etkiye sahip olan fenolikler ve antioksidanlar bakımından zengin olduğu belirlenmiștir.

\section{Physical and Biochemical Properties of 'Ekmek' Quince Cultivar Grown in Taşova (Amasya) District}

\section{Article Info}

Recieved: 09.07.2021

Accepted: 05.11.2021

Online December 2021

DOI: $10.53433 /$ yyufbed.967975

Keywords

Quince,

Fruit weight,

Sugar,

Phenolic,

Antioxidant

\begin{abstract}
The study was conducted to determine physical and biochemical properties of 'Ekmek' quince cultivar grown in Taşova (Amasya) district. Fruit weight, fruit flesh firmness, soluble solids content, titratable acidity, vitamin $\mathrm{C}$, glucose, sucrose, fructose, total sugar, total phenolic, total flavonoid, antioxidant activity (according to DPPH and FRAP assays) in the study were determined as $305.43 \mathrm{~g}, 62.50 \mathrm{~N}, \% 11.64, \% 0.83,11.60 \mathrm{mg} / 100 \mathrm{~g}, 3.10 \mathrm{~g} / 100 \mathrm{ml}, 1.87 \mathrm{~g} / 100 \mathrm{ml}$, $7.62 \mathrm{~g} / 100 \mathrm{ml}, 121.8 \mathrm{mg} / 100 \mathrm{~g}, 18.4 \mathrm{mg} / 100 \mathrm{~g}, 0.46 \mathrm{mmol} / 100 \mathrm{~g}$ and 2.67 $\mathrm{mmol} / 100 \mathrm{~g}$, respectively. As a result, it was determined that 'Ekmek' quince cultivar is rich in terms of phenolics and antioxidants that beneficial human health, protective effect against diseases.
\end{abstract}

\section{Giriş}

Ayvanın anavatanı Kuzey Anadolu, Kuzey Kafkasya, Hazar Denizi kıyıları ve Kuzey-Batı İran olup (Özçağıran ve ark., 2014), yabanileri Güneydoğu Avrupa ve Orta Asya'da doğal olarak yayılış 
gösterir (Rodriguez-Guisado ve ark., 2009). Ayva dünya üzerinde Avustralya kıtası hariç, diğer kıta ve ülkelerde yetiştirilir. Bu meyve türü, kültürü yapılan diğer meyve türlerine göre çok yaygınlaşmamış ve üretimi sınırlı kalmıştır (Özçağıran ve ark., 2014).

Dünyada ayva üretimi yaklaşık 689 bin tondur. Dünya ayva üretimi bakımından Türkiye (176 479 t) lider konumda olup, ülkemizi Çin (118 593 t), Özbekistan (76 865 t), İran (76 508 t), Fas (59 444 t) ve Azerbaycan (32 290 t) takip etmektedir (FAO, 2020). Dünya üzerinde ayva yetiştiriciliğinde kullanılan çok az sayıda yabancı çeşit bulunmaktadır (Oliveira ve ark., 2007). Bunlardan en önemlileri 'Smyrna', 'Portugal', 'Spahan', 'Morova', 'Pineapple', Van Deman', 'Boterno', 'Champion', 'Meeh' ve 'Orage' çeşitleridir (Dehbi ve ark., 2014). 'Champion' çeşidi dünya üzerinde ayva yetiştiriciliğinde tercih edilen önemli bir çeşittir (Hricovsky ve ark., 2003). Ülkemizde ise 'Ekmek', 'Limon', 'Eşme', 'Demir' ve 'Bardak' yetiştiriciliği yapılan önemli ayva çeşitleridir. Bunlardan 'Ekmek' ve 'Limon' yaygın olarak yetiştirilen çeşitlerdir (Soylu, 1997).

Ayva çeşitleri meyve şekline göre elma ve armut biçimdeki ayvalar olarak iki gruba ayrılır (Özbek, 1978; Hricovsky ve ark., 2003). Ülkemizde yetiştirilen çeşitlerin büyük çoğunluğu armut şeklindedir (Özbek, 1978). Bu meyve şekline sahip ayvalar daha yumuşak ve daha az taş hücresine sahiptir. Elma şeklindeki ayvalar ise kuru ve daha sert meyve etine sahip olup, armut şeklindeki ayvalara göre daha aromalıdır (Hricovsky ve ark., 2003). Ayva meyvesi taze tüketimin yanında kurutularak ve farklı ürünlere işlenerek de (marmelat, reçel, jöle, meyve suyu, püre ve aromatik bileşiklerin ekstraksiyonunda) kullanılır (Silva ve ark., 2006; Sharma ve ark., 2011; Rubinskiene ve ark., 2014).

Ayva, insan sağlığını teşvik eden fenolikler ve antioksidanlar bakımından zengin olup (Silva ve ark., 2004), potasyum, fosfor ve kalsiyum gibi mineral maddeler, vitaminler, organik asitler ve şekerlerin önemli bir kaynağıdır (Fattouch ve ark., 2007; Rodriguez-Guisado ve ark., 2009). Ayva içeriğindeki antioksidanlar ve fenolik bileşiklerin yanı sıra (Legua ve ark., 2013; Grygorieva ve ark., 2020), anti-kanserojen (Carvalho ve ark., 2010), anti-inflamatuar (iltihap sökücü) (Essafi-Benkhadir ve ark., 2012), anti-ülseratif (Hamauzu ve ark., 2006), anti-alerjik, anti-mikrobiyal (Shaida ve ark., 2020) ve hipoglisemik (Szychowski ve ark., 2014) özellikleri nedeniyle ilgi çekici olup, bu özelliklerinden dolayı birçok hastalığa karşı koruyucu ve önleyici bir etkiye sahiptir (Sharma ve ark., 2011; Wojdylo ve ark., 2013).

Ülkemizde ayva üzerine yapılan çalışmaların büyük çoğunluğu verim ve meyve kalite özelliklerini belirlemeye yönelik olup (Ercişli ve ark., 1999; Koyuncu ve ark., 1999; Gerçekcioğlu ve ark., 2014; Bolat \& İkinci, 2015), biyokimyasal özelliklerin incelenmesine yönelik araştırmalar ise sınırlı sayıdadır (Karadeniz ve ark., 2005). Ayrıca ülkemizde yetiştirilen ayva çeşitlerinin farklı lokasyonlarda meyve özelliklerinin incelendiği çalışma sayısı da oldukça azdır. Çalışmanın yürütüldüğü Taşova yöresi ülkemiz ayva üretimi bakımından 8. sırada yer alan Amasya ili ayva üretiminin yaklaşık \%48'ini karşılamaktadır. Bunun yanında, ayva yetiştiriciliği bakımından önemli bir potansiyele sahip bölgede 2016 y1lından sonra ayva üretimi önemli miktarda artmıştır (TUIK, 2021). Bu çalışma Taşova yöresinde yetiştirilen önemli bir ayva çeşidimiz olan 'Ekmek' çeşidinin fiziksel ve biyokimyasal özelliklerini belirlemek amaciyla yürütülmüştür.

\section{Materyal ve Yöntem}

Çalışmada materyal olarak Taşova (Amasya) yöresinde çöğür anaç üzerine aş11 Ekmek ayva çeşidi ile kurulmuş 12 yaşlı ayva bahçesinden alınan meyve örnekleri kullanılmıştır. Çalışma 2017 yılında yürütülmüştür. Çalışmanın yürütüldüğü bahçe sıra üzeri $4 \mathrm{~m}$ ve sıra arası $4.5 \mathrm{~m}$ olarak tesis edilmiştir. Çalışma süresince kültürel ve teknik uygulamalar düzenli olarak yapılmıştır.

Çalışma 3 tekerrürlü ve her tekerrürde 3 ağaç olacak şekilde planlanmıştır. Hasat zamanında her ağaçtan 10 meyve derilmiştir. Hasat işlemi meyve kabuk renginin sarıya döndüğü ve kabuk üzerindeki havın el ile kolayca silindiği dönemde yapılmıştır. Hasat edilen meyvelerde fiziksel ve biyokimyasal özellikler incelenmiştir. Fiziksel özelliklerden meyve ağıllı̆̆ $0.01 \mathrm{~g}$ hassasiyetindeki dijital terazi (Radwag, AS 220/C/2, Polonya) ile tartılarak, meyve eni, genişliği ve boyu $0.01 \mathrm{~mm}$ hassasiyetindeki dijital kumpas (Mitutuyo, CD-15CP, Japonya) ile ölçülerek, meyve eti sertliği ise el penetrometresinin (Effegi, FT 327, İtalya) 7.9 mm'lik ucu kullanılarak belirlenmiş̧ir (Şen ve ark., 1999; Gerçekcioğlu ve ark., 2014). Biyokimyasal özellikler olarak ise $\mathrm{pH}$, suda çözünebilir kuru madde, titre edilebilir asitlik, C vitamini, şeker içeriği (glikoz, sukroz, fruktoz ve toplam şeker), toplam fenolik, toplam flavonoid ve antioksidan aktivitesi (DPPH ve FRAP testlerine göre) incelenmiştir. 


\section{1. pH, suda çözünebilir kuru madde (\%) ve titre edilebilir asitlik (\%)}

Meyve suyu çıkarılan örneklerde pH değeri dijital pH metre (Hanna, HI4221, ABD) ve suda çözünebilir kuru madde miktarı dijital refraktrometre (Atago, PAL-1, ABD) ile belirlenmiştir. Titre edilebilir asitlik için meyve suyu saf su ile seyreltilmiş (1:1) ve elde edilen karışımın pH değeri 8.1 oluncaya kadar $0.1 \mathrm{~N} \mathrm{NaOH}$ ile titre edilmiştir. Sonuçlar malik asit cinsinden \% olarak ifade edilmiştir.

\subsection{C vitamini içeriği $(\mathrm{mg} / 100 \mathrm{~g})$}

C vitamini içeriği reflektometre (RQ flex, Plus 10, Merck, Almanya) yardımıyla meyve suyunda belirlenmiş ve $\mathrm{mg} / 100 \mathrm{~g}$ olarak ifade edilmiştir.

\section{3. Şeker içerikleri $(\mathrm{g} / \mathbf{1 0 0} \mathrm{ml})$}

Şekerlerden glukoz, sukroz, fruktoz ve toplam şeker içerikleri tespit edilmiştir. Şeker içerikleri reflektometre (RQ flex, Plus 10, Merck, Almanya) yardımıyla meyve suyunda belirlenmiştir. Okunan değerler $\mathrm{g} / 100 \mathrm{ml}$ olarak ifade edilmiştir.

\subsection{Toplam fenolik (mg/100 g)}

Toplam fenolik içeriği Beyhan ve ark. (2010)'nın yöntemine göre Folin-Ciocalteu's kimyasalı kullanılarak belirlenmiştir. Hazırlanan stok çözeltiden $500 \mu \mathrm{L}$ alınmış ve üzerine $4.1 \mathrm{~mL}$ saf su, $100 \mu \mathrm{L}$ Folin-Ciocalteu's ayracı ve \%2'lik $\mathrm{NaCO}_{3}$ ilave edilmiştir. 2 saat süre ile inkübasyona bırakılan numuneler spektrofotometre'de (Shimadzu, UVmini-1240, Japonya) $760 \mathrm{~nm}$ dalga boyunda ölçülmüştür. Sonuçlar gallik asit cinsinden $\mathrm{mg} / 100 \mathrm{~g}$ olarak ifade edilmiştir.

\subsection{Toplam flavonoid $(\mathrm{mg} / 100 \mathrm{~g})$}

Toplam falvonoid içeriği Zhishen ve ark. (1999)'nın yöntemine göre belirlenmiştir. Hazırlanan stok çözeltiden $1000 \mu \mathrm{L}$ alınmış ve üzerine $3.3 \mathrm{~mL}$ methanol, $100 \mu \mathrm{L} \% 5$ 'lik $\mathrm{NaNO}_{2}$ ve $100 \mu \mathrm{L} \% 10^{\prime}$ 'luk $\mathrm{AlCl}_{3}$ ilave edilmiştir. $30 \mathrm{dk}$ süre ile inkübasyona bırakılan numuneler spektrofotometre'de $415 \mathrm{~nm}$ dalga boyunda ölçülmüştür. Sonuçlar kuersetin cinsinden mg/100 g olarak ifade edilmiştir.

\subsection{Antioksidan aktivitesi $(\mathrm{mmol} / 100 \mathrm{~g})$}

\subsubsection{DPPH yöntemi}

DPPH analizi için, hazırlanan stok çözeltiden $200 \mu \mathrm{L}$ alınarak üzerine $2.8 \mathrm{~mL}$ etil alkol ve 0.26 mM DPPH çözeltisi ilave edilmiştir. Hazırlanan numuneler $30 \mathrm{dk}$ inkübasyon işleminden sonra spektrofotometre'de $517 \mathrm{~nm}$ dalga boyunda ölçülmüş̧ür. Sonuçlar torolox cinsinden mmol/100 g olarak ifade edilmiştir (Blois, 1958).

\subsubsection{FRAP yöntemi}

FRAP analizi için, hazırlanan stok çözeltiden $200 \mu \mathrm{L}$ alınarak üzerine $1050 \mu \mathrm{L}$ fosfat tamponu ve $1250 \mu \mathrm{L}$ potasyum ferrik siyanit ilave edilmiştir. Hazırlanan numuneler $30 \mathrm{dk}$ süre ile $50^{\circ} \mathrm{C}$ de inkübasyon işlemine tabi tutulmuştur. İnkübasyon işeleminden sonra numunelerin üzerine $1250 \mu \mathrm{L}$ TCA ve $250 \mu \mathrm{L}$ demir klorür ilave edilerek, spektrofotometre'de $700 \mathrm{~nm}$ dalga boyunda ölçülmüştür. Sonuçlar torolox cinsinden mmol/100 g olarak ifade edilmiştir (Benzie \& Strain, 1996).

\section{7. İstatistiki Analizler}

Verilerin değerlendirilmesinde SPSS 23.0 istatistik paket programı kullanılmıştır. İncelenen özelliklere ait standart sapma ve varyasyon katsayısı (VK) belirlenmiştir. 


\section{Bulgular ve Tartışma}

İncelenen Ekmek ayva çeşidinde, meyve iriliği üzerine etkili olan meyve ağırlı̆g $305.43 \mathrm{~g}$, meyve eni $81.27 \mathrm{~mm}$, meyve genişliği $84.52 \mathrm{~mm}$ ve meyve boyu $86.42 \mathrm{~mm}$ olarak belirlenirken, önemli bir kalite özelliği olan ve ürünün muhafaza ömrünü etkileyen meyve eti sertliği ise $62.50 \mathrm{~N}$ olarak ölçülmüş̧ür (Çizelge 1). Ülkemizde Ekmek ayva çeşidi üzerine yürütülen çalışmalarda meyve ağırlığı 186.0-275.71 g, meyve eni 74.75-83.20 mm, meyve boyu 73.34-83.50 mm ve meyve eti sertliği 13.05$81.03 \mathrm{~N}$ arasında bildirilmiştir (Ercişli ve ark., 1999; Koyuncu ve ark., 1999). Ekmek ayva çeşidinin meyve ağırlığı ve meyve boyu değerleri araştırıcıların bulgularından yüksek bulunurken; meyve eti sertliği, meyve eni ve genişliği değerleri ise benzerlik göstermiştir. Meyve ağırlığ ve meyve boyu bakımından görülen farklılıkların ekolojik koşullardan, teknik ve kültürel uygulamalardan kaynaklı olabileceği düşünülmektedir.

Çizelge 1. Ekmek ayvasının meyve ağırlığı (g), meyve eni, meyve genişliği, meyve boyu (mm) ve meyve eti sertliği değerleri

\begin{tabular}{lll}
\hline & Ortalama \pm Standart sapma & VK \\
\hline Meyve ağırlığ $(\mathrm{g})$ & $305.43 \pm 40.36$ & 0.13 \\
Meyve eni (mm) & $81.27 \pm 8.93$ & 0.11 \\
Meyve genişliği (mm) & $84.52 \pm 7.81$ & 0.09 \\
Meyve boyu (mm) & $86.42 \pm 12.21$ & 0.14 \\
Meyve eti sertliği (N) & $62.50 \pm 8.50$ & 0.14 \\
\hline
\end{tabular}

Meyve kalitesi üzerine etkili olan ve tüketici albenisini etkileyen $\mathrm{pH}$, suda çözünebilir kuru madde ve titre edilebilir asitlik değerleri incelenen Ekmek ayva çeşidinde sırasıyla 4.16, \%11.64 ve $\% 0.83$ olarak tespit edilmiştir (Çizelge 2). Bu parametreler Van ili ve Oltu (Erzurum) ilçesinde yetiştirilen Ekmek ayva çeşidinde sırasıyla 3.25-4.06, \%13.18-14.15 ve \%1.58-0.56 arasında bildirilmiştir (Koyuncu ve ark., 1999; Ercişli ve ark., 1999). Çalışmada özellikle suda çözünebilir kuru madde ve titre edilebilir asitlik içeriği bakımından elde edilen bulgular araştırıcıların bulgularından farklı1ık göstermektedir. Bu özellikler bakımından görülen farklılıklar başta ekolojik faktörler ve bakım koşulları olmak üzere meyvenin olgunluk durumuyla da ilgilidir.

Çizelge 2. Ekmek ayvasının pH, suda çözünebilir kuru madde (\%), titre edilebilir asitlik (\%) ve C vitamini içeriği $(\mathrm{mg} / 100 \mathrm{~g})$

\begin{tabular}{lll}
\hline & Ortalama \pm Standart sapma & VK \\
\hline $\mathrm{pH}$ & $4.16 \pm 0.01$ & 0.00 \\
Suda çözünebilir kuru madde (\%) & $11.64 \pm 0.37$ & 0.03 \\
Titre edilebilir asitlik (\%) & $0.83 \pm 0.012$ & 0.01 \\
$\mathrm{C}$ vitamini (mg/100 g) & $11.60 \pm 0.08$ & 0.01 \\
\hline
\end{tabular}

İnsan sağlı̆̆ üzerine önemli bir etkisi olan C vitamini, incelenen Ekmek ayva çeşidinde 11.60 mg/100 g olarak belirlenirken (Çizelge 2), Oltu (Erzurum) ilçesinde aynı ayva çeşidinde yürütülen araştırmada $3.68 \mathrm{mg} / 100 \mathrm{~g}$ olarak bildirilmiştir (Ercişli ve ark., 1999). Bunun yanında farklı ülkelerde yetiştirilen ayva çeşit ve genotipleri ile yapılan araştırmalarda $C$ vitamini içeriği en düşük $5.9 \mathrm{mg} / 100$ $\mathrm{g}$, en yüksek ise $79.31 \mathrm{mg} / 100 \mathrm{~g}$ (Rop ve ark., 2011; Wojdylo ve ark., 2013; Rasheed ve ark., 2018) olarak rapor edilmiştir. Elde edilen C vitamini değeri, Oltu (Erzurum) ilçesinde yetiştirilen Ekmek ayva çeşidinden elde edilen değerden yüksek, yabancı çeşit ve genotiplerin birçoğuna ait değerlerle ise benzerlik göstermektedir. $\mathrm{C}$ vitamini içeriği bakımından görülen farklılıkların genetik yapı, ekolojik koşullar ve bakım şartlarından kaynaklı olduğu ifade edilebilir. 
Çalışmada incelenen Ekmek ayva çeşidinde glikoz içeriği $3.10 \mathrm{~g} / 100 \mathrm{ml}$, sukroz içeriği 1.87 $\mathrm{g} / 100 \mathrm{ml}$, fruktoz içeriği $7.62 \mathrm{~g} / 100 \mathrm{ml}$ ve toplam şeker içeriği $12.59 \mathrm{~g} / 100 \mathrm{ml}$ olarak tespit edilmiştir (Çizelge 3). Mevcut çalışmada Ekmek ayva çeşidinin şeker içerikleri Tuna-Güneş \& Köksal, (2005)'1n Eşme (glikoz $3.55 \mathrm{~g} / 100 \mathrm{ml}$, sukroz $2.20 \mathrm{~g} / 100 \mathrm{ml}$ ve fruktoz $6.95 \mathrm{~g} / 100 \mathrm{ml}$ ) ve Çukurgöbek (glikoz $4.55 \mathrm{~g} / 100 \mathrm{ml}$, sukroz $2.35 \mathrm{~g} / 100 \mathrm{ml}$ ve fruktoz $8.45 \mathrm{~g} / 100 \mathrm{ml}$ ) ayva çeşitlerinde bildirdiği şeker içerikleriyle uyumlu bulunmuştur. Bunun yanında, farklı araştırıcılar tarafından (Rodriguez-Guisado ve ark., 2009; Leonel ve ark., 2016) yabancı ayva çeşit ve klonlarında bildirilen glikoz (4.08-5.61 g/100 $\mathrm{ml})$, sukroz $(1.51-2.41 \mathrm{~g} / 100 \mathrm{ml})$, fruktoz $(5.31-10.89 \mathrm{~g} / 100 \mathrm{ml})$ ve toplam şeker $(9.50-17.93 \mathrm{~g} / 100 \mathrm{ml})$ değerleriyle de benzer olduğu tespit edilmiştir.

Çizelge 3. Ekmek ayvasının şeker içeriği (g/100 ml)

\begin{tabular}{lll}
\hline & Ortalama \pm Standart sapma & VK \\
\hline Glikoz $(\mathrm{g} / 100 \mathrm{ml})$ & $3.10 \pm 0.08$ & 0.03 \\
Sukroz $(\mathrm{g} / 100 \mathrm{ml})$ & $1.87 \pm 0.07$ & 0.04 \\
Fruktoz $(\mathrm{g} / 100 \mathrm{ml})$ & $7.62 \pm 0.32$ & 0.04 \\
Toplam şeker $(\mathrm{g} / 100 \mathrm{ml})$ & $12.59 \pm 0.38$ & 0.03 \\
\hline
\end{tabular}

Antioksidan aktiviteye sahip fenolikler, insan sağlığını teşvik eden önemli bileşiklerdir (Silva ve ark., 2004). Toplam fenolik içeriği, incelenen Ekmek ayva çeşidinde $121.8 \mathrm{mg} / 100 \mathrm{~g}$ olarak belirlenmiştir (Çizelge 4). Ankara ekolojik koşullarında benzer ayva çeşidi ile yürütülen araştırmada toplam fenolik içeriği $376.3 \mathrm{mg} / 100 \mathrm{~g}$ olarak bildirilmiştir (Karadeniz ve ark. 2005). Bunun yanında yabancı ayva çeşit ve genotipleri ile yürütülen araştırmalarda toplam fenolik içeriği İspanya' da 40-100 mg/100 g (Legua ve ark., 2013), Macaristan'da 3.92-12.83 mg/100 g (Papp ve ark., 2013), Strbistan'da 71.03-158.89 mg/100 g (Stojanovic ve ark., 2017), Pakistan'da 65.73-68.13 mg/100 g (Rasheed ve ark., 2018) arasında tespit edilmiştir. İncelenen Ekmek ayva çeşidinin toplam fenolik içeriği Ankara ekolojik koşullarında yetiştirilen Ekmek ayva çeşidinden düşük, yabancı çeşit ve genotiplerin büyük bir çoğunluğundan ise yüksek bulunmuştur. Toplam fenolik içeriği bakımından görülen farklılıkların genetik yapıdan, ekolojik koşullardan, meyvenin olgunluk durumundan, teknik ve kültürel uygulamalardan kaynaklanabileceği düşünülmektedir.

Çizelge 4. Ekmek ayvasının toplam fenolik (mg/100 g), toplam flavonoid (mg/100 g) ve antioksidan aktivitesi (mmol/100 g) (DPPH ve FRAP)

\begin{tabular}{lll}
\hline & Ortalama \pm Standart sapma & VK \\
\hline Toplam fenolik $(\mathrm{mg} / 100 \mathrm{~g})$ & $121.8 \pm 7.37$ & 0.06 \\
Toplam flavonoid $(\mathrm{mg} / 100 \mathrm{~g})$ & $18.4 \pm 0.75$ & 0.04 \\
DPPH $(\mathrm{mmol} / 100 \mathrm{~g})$ & $0.46 \pm 0.04$ & 0.08 \\
FRAP $(\mathrm{mmol} / 100 \mathrm{~g})$ & $2.67 \pm 0.04$ & 0.02 \\
\hline
\end{tabular}

Mevcut çalışmada incelenen Ekmek ayva çeşidinde toplam flavonoid içeriği $18.4 \mathrm{mg} / 100 \mathrm{~g}$ olarak tespit edilirken (Çizelge 4), bu değerin aynı çeşit ile Ankara ekolojik koşullarında yürütülen araştırmada elde edilen değerden $(172.3 \mathrm{mg} / 100 \mathrm{~g})$ düşük olduğu belirlenmiştir (Karadeniz ve ark., 2005). Buna karş11ı, Stojanovic ve ark., (2017)'nın Sırbistan'da yetiştirilen farklı ayva çeşitlerinde bildirdiği toplam flavonoid içeriği değerleriyle $(17.28-44.65 \mathrm{mg} / 100 \mathrm{~g})$ ise uyumlu olduğu tespit edilmiştir. Görülen farklılıkların ekolojik koşullardan, meyvenin olgunluk durumundan ve kültürel uygulamalardan kaynaklı olduğu ifade edilebilir.

İnsan sağlığını teşvik eden antioksidanlar hastalık risklerinin azaltılması ve önlenmesi bakımından önemlidir (Karadeniz ve ark., 2005). Antioksidan aktivitesi, incelenen Ekmek ayva çeşidinde DPPH testine göre $0.46 \mathrm{mmol} / 100 \mathrm{~g}$, FRAP testine göre ise $2.67 \mathrm{mmol} / 100 \mathrm{~g}$ olarak belirlenmiştir (Çizelge 4). Antioksidan aktivitesi, Macaristan'da yetiştirilen farklı ayva çeşitlerinde 
FRAP testine göre 5.99-63.10 mmol/100 g arasında bildirilmiştir (Papp ve ark., 2013). Bunun yanında ABTS yöntemi kullanılarak yapılan araştırmalarda aktioksidan aktivitesi, İspanya'da yetiştirilen farklı ayva genotipleri ve klonlarında 18.6-99.0 mg/100 g arasında rapor edilmiştir (Legua ve ark., 2013; Szychowski ve ark., 2014). Ekmek ayva çeşidinin antioksidan aktivitesi değeri aynı yöntemi kullanan araştırıcıların inceledikleri çeşitlere ait değerlerden düşük bulunmuştur. Antioksidan aktivitesi bakımından görülen farklılığın genetik yapı, ekolojik koşullar, meyvenin olgunluk durumu, teknik ve kültürel uygulamalar ile ilişkili olduğu düşünülmektedir.

\section{Sonuç}

'Ekmek' ayva çeşidinin fiziksel ve biyokimyasal özelliklerinin incelendiği çalışmada, bu çeşidin insan sağlığını teşvik eden ve hastalıklara karşı engelleyici ve koruyucu bir etkiye sahip olan fenolik bileşikler ve antioksidanlar bakımından zengin olduğu belirlenmiştir. Bunun yanında 'Ekmek' ayva çeşidi incelenen özellikler bakımından ülkemizde ve dünyada yetiştirilen birçok ayva çeşidine yakın ve hatta bazılarından daha yüksek değerlere sahip olmuştur.

\section{Kaynakça}

Benzie, I. F., \& Strain, J. J. (1996). The ferric reducing ability of plasma (FRAP) as a measure of "antioxidant power": the FRAP assay. Analytical Biochemistry, 239(1), 70-76. https://doi.org/10.1006/abio.1996.0292

Beyhan, Ö., Elmastaş, M., \& Gedikli, F. (2010). Total phenolic compounds and antioxidant capacity of leaf, dry fruit and fresh fruit of feijoa (Acca sellowiana, Myrtaceae). Journal of Medicinal Plant Research, 4, 1065-1072. https://doi.org/10.5897/JMPR10.008

Blois, M. S. (1958). Antioxidant determinations by the use of a stable free radical. Nature, 181(4617), 1199-1200. https://doi.org/10.1038/1811199a0

Bolat, İ., \& İkinci, A. (2015). Eşme ayva (Cydonia oblonga Miller) çeşidinin GAP Bölgesindeki performans1. Harran Tartm ve Gida Bilimleri Dergisi, 19(1), 16-23.

Carvalho, M., Silva, B. M., Silva, R., Valentao, P., Andrade, P. B., \& Bastos, M. L. (2010). First report on Cydonia oblonga Miller anticancer potential: differential antiproliferative effect against human kidney and colon cancer cells. Journal of Agricultural and food Chemistry, 58(6), 33663370. https://doi.org/10.1021/jf903836k

Dehbi, F., Hasib, A., Ouatmane, A., Elbatal, H., \& Jaouad, A. (2014). Physicochemical characteristics of Moroccan prickly pear juice (Opuntia ficus indica L.). International Journal of Emerging Technology and Advanced Engineering, 4(4), 300-6.

Ercişli, S., Güleryüz, M., \& Eşitken, A. (1999). Oltu ilçesinde yetiştirilen ayva çeşitlerinin meyve özellikleri üzerinde bir araştırma. Anadolu Dergisi, 9(2), 32-40.

Essafi-Benkhadir, K., Refai, A., Riahi, I., Fattouch, S., Karoui, H., \& Essafi, M. (2012). Quince (Cydonia oblonga Miller) peel polyphenols modulate LPS-induced inflammation in human THP-1-derived macrophages through NF- $\mathrm{BB}$, p38MAPK and Akt inhibition. Biochemical and $\begin{array}{lll}\text { Biophysical Research } & \text { Communications, 418(1), }\end{array}$ https://doi.org/10.1016/j.bbrc.2012.01.003

FAO, (2020). Food and Agriculture Organization of the United Nations. www.fao.org/faostat/en/\#data/QC Erişim tarihi: 17.02.2021.

Fattouch, S., Caboni, P., Coroneo, V., Tuberoso, C. I., Angioni, A., Dessi, S., Marzouki, N., \& Cabras, P. (2007). Antimicrobial activity of Tunisian quince (Cydonia oblonga Miller) pulp and peel polyphenolic extracts. Journal of Agricultural and Food Chemistry, 55(3), 963-969. https://doi.org/10.1021/jf062614e

Gerçekcioğlu, R., Gencer, S., \& Atasever, Ö. Ö. (2014). Tokat ekolojisinde yetiştirilen "Eşme" ve "Limon" ayva (Cydonia vulgaris L.) çeşitlerinin bitkisel ve pomolojik özellikleri. International Journal of Agricultural and Natural Sciences, 7(1), 01-05.

Grygorieva, O., Klymenko, S., Vergun, O., Mňahončáková, E., Brindza, J., Terentjeva, M., \& Ivanišová, E. (2020). Evaluation of the antioxidant activity and phenolic content of Chinese quince (Pseudocydonia sinensis Schneid.) fruit. Acta Scientiarum Polonorum Technologia Alimentaria, 19(1), 25-36. http://dx.doi.org/10.17306/J.AFS.2020.0738 
Hricovsky, I., Reznícek, V., \& Sus, J. (2003). Jablone a hrusne, kdoulone, mispule. Príroda, Bratislava, $12,53-54$.

Karadeniz, F., Burdurlu, H. S., Koca, N., \& Soyer, Y. (2005). Antioxidant activity of selected fruits and vegetables grown in Turkey. Turkish Journal of Agriculture and Forestry, 29(4), 297-303.

Koyuncu, F., Yılmaz, H., \& Koyuncu, M. (1999). Ekmek ayvasının Van ekolojik koşullarında bazı ağaç ve meyve özelliklerinin belirlenmesi üzerine bir araştırma. Yüzüncü Yıl Üniversitesi Tarım Bilimleri Dergisi, 9(1), 37-40.

Legua, P., Serrano, M., Melgarejo, P., Valero, D., Martínez, J. J., Martínez, R., \& Hernández, F. (2013). Quality parameters, biocompounds and antioxidant activity in fruits of nine quince (Cydonia oblonga Miller) accessions. Scientia Horticulturae, 154, 61-65. https://doi.org/10.1016/j.scienta.2013.02.017

Leonel, M., Leonel, S., Tecchio, M. A., Mischan, M. M., Moura, M. F., \& Xavier, D. (2016). Characteristics of quince fruits cultivars' (Cydonia oblonga Mill.) grown in Brazil. Australian Journal of Crop Science, 10(5), 711. https://doi/abs/10.3316/informit.203321426595075

Oliveira, A. P., Pereira, J. A., Andrade, P. B., Valentão, P., Seabra, R. M., \& Silva, B. M. (2007). Phenolic profile of Cydonia oblonga Miller leaves. Journal of Agricultural and Food Chemistry, 55(19), 7926-7930. https://doi.org/10.1021/jf0711237

Özbek, S. (1978). Özel Meyvecilik. Çukurova Üniversitesi Ziraat Fakültesi Yayınları, Adana, Türkiye.

Özçağıran, R., Ünal, A., Özeker, E., \& İsfendiyaroğlu, M. (2014). Ilıman İklim Meyve Türleri Yumuşak Çekirdekli Meyveler. Cilt-III, Ege Üniversitesi Ziraat Fakültesi Yayınları, İzmir, Türkiye.

Papp, N., Szabó, T., Szabó, Z., Nyéki, J., \& Hegedüs, A. (2013). Antioxidant capacity and total polyphenolic content in quince (Cydonia oblonga Mill.) fruit. International Journal of Horticultural Science, (3-4), 33-35.

Rasheed, M., Hussain, I., Rafiq, S., Hayat, I., Qayyum, A., Ishaq, S., \& Awan, M. S. (2018). Chemical composition and antioxidant activity of quince fruit pulp collected from different locations. International Journal of Food Properties, 21(1), 2320-2327. https://doi.org/10.1080/10942912.2018.1514631

Rodríguez-Guisado, I., Hernández, F., Melgarejo, P., Legua, P., Martínez, R., \& Martínez, J. J. (2009). Chemical, morphological and organoleptical characterisation of five Spanish quince tree clones (Cydonia oblonga Miller). Scientia Horticulturae, 122(3), 491-496. https://doi.org/10.1016/j.scienta.2009.06.004

Rop, O., Balik, J., Řezníček, V., Juríková, T., Škardová, P., Salaš, P., Sochor, J., Mlcek, J., \& Kramáŕová, D. (2011). Chemical characteristics of fruits of some selected quince (Cydonia oblonga Mill.) cultivars. Czech Journal of Food Sciences, 29(1), 65-73. https://doi.org/10.17221/212/2009-CJFS

Rubinskiene, M., Viškelis, P., Viškelis, J., Bobinaite, R., Shalkevich, M., Pigul, M., \& Urbonaviciene, D. (2014). Biochemical composition and antioxidant activity of Japanese quince (Chaenomeles japonica) fruit, their syrup and candied fruit slices. Sodininkystè ir Daržininkystè, 33(1-2), 4552.

Sharma, R., Joshi, V. K., \& Rana, J. C. (2011). Nutritional composition and processed products of quince (Cydonia oblonga Mill.). Indian Journal of Natural Products and Resources, 2(3), 354-357.

Shaida, B., Singh, N. B., \& Singh, K. (2020). In-Vitro Evaluation of Anti-Inflammatory and AntiMicrobial Properties of Ethanolic Extract of Cydonia Oblonga Seeds. Journal of Scientific \& Industrial Research, 79(1), 49-52.

Silva, B. M., Andrade, P. B., Gonçalves, A. C., Seabra, R. M., Oliveira, M. B., \& Ferreira, M. A. (2004). Influence of jam processing upon the contents of phenolics, organic acids and free amino acids in quince fruit (Cydonia oblonga Miller). European Food Research and Technology, 218(4), 385-389. https://doi.org/10.1007/s00217-003-0845-6

Silva, B. M., Andrade, P. B., Martins, R. C., Seabra, R. M., \& Ferreira, M. A. (2006). Principal component analysis as tool of characterization of quince (Cydonia oblonga Miller) jam. Food Chemistry, 94(4), 504-512. https://doi.org/10.1016/j.foodchem.2004.11.045

Soylu, A. (1997). Ilıman İklim Meyveleri-II. Uludağ Üniversitesi Ders Notları, Bursa, Türkiye.

Stojanović, B. T., Mitić, S. S., Stojanović, G. S., Mitić, M. N., Kostić, D. A., Paunović, D. Đ., Arsic, B. B., \& Pavlović, A. N. (2017). Phenolic profiles and metal ions analyses of pulp and peel of fruits 
and seeds of quince (Cydonia oblonga Mill.). Food Chemistry, 232, 466-475. https://doi.org/10.1016/j.foodchem.2017.04.041

Szychowski, P. J., Munera-Picazo, S., Szumny, A., Carbonell-Barrachina, Á. A., \& Hernández, F. (2014). Quality parameters, bio-compounds, antioxidant activity and sensory attributes of Spanish quinces (Cydonia oblonga Miller). Scientia Horticulturae, 165, 163-170. https://doi.org/10.1016/j.scienta.2013.11.028

Şen, S. M., Karadeniz, T., \& Balta, F. (1993). Tirebolu (Harkköyü) yöresinde yetiştirilen önemli mahalli ayva çeşitleri üzerinde morfolojik ve pomolojik çalışmalar. Yüzüncü Yıl Üniversitesi Ziraat Fakültesi Dergisi, 3(1-2), 205-219.

TUİK, (2020). Türkiye İstatistik Kurumu. https://biruni.tuik.gov.tr/medas/?kn=92\&locale=tr Erişim tarihi: 12.10 .2021$.

Tuna-Gunes, N., \& Koksal, A. I. (2005). Ethylene biosynthesis of quince during storage. Acta Horticulturae, 682(1), 177. 10.17660/ActaHortic.2005.682.17

Wojdylo, A., Oszmianski, J., \& Bielicki, P. (2013). Polyphenolic composition, antioxidant activity, and polyphenol oxidase (PPO) activity of quince (Cydonia oblonga Miller) varieties. Journal of Agricultural and Food Chemistry, 61(11), 2762-2772. https://doi.org/10.1021/jf304969b

Zhishen, J., Mengcheng, T., \& Jianming, W. (1999). The determination of flavonoid contents in mulberry and their scavenging effects on superoxide radicals. Food Chemistry, 64(4), 555-559. https://doi.org/10.1016/S0308-8146(98)00102-2 